\title{
A REPORT ON THE USE OF THE KANSAS SILENT READING TESTS WITH OVER ONE HUNDRED THOUSAND CHILDREN
}

\author{
WALTER S. MONROE \\ Kansas Slate Normal School, Emporia, Kansas
}

This report on silent reading is based upon the use of the Kansas Silent Reading Tests (devised by F. J. Kelly) during the years 1915-'16 and 1916-'17. Within this time more than 700,000 copies of these tests have been distributed by the Bureau of Educational Measurements and Standards. Out of the total number of tests distributed, reports have been received from more than 100,000 pupils in 160 cities. These tests are so well known that they will be described only briefly here. An account of their derivation may be found in the Journal of Educational Psychology for February, 1916. Sample copies of these tests may be obtained from the Bureau of Educational Measurements and Standards, Emporia, Kans.

Three tests make up the series. Test $I$ is for grades $3,4,5$. Test II, for grades 6, 7, 8; and Test III, for grades 9, 10, 11, 12 . Each tests consists of sixteen exercises. The exercise requires the pupil to make a definite response. The tests may be said to be objective in the sense that there is little opportunity for differences of opinion in marking the test papers. The nature of the exercises is illustrated by the following selected from Test II:

Value

1.0

No. 1.

The air near the ceiling of a room is warm, while that on the floor is cold. Two boys are in the room, James on the floor and Harry on a box eight feet high. Which boy has the warmer place?

No. 3.

We can see through glass, so we call it transparent. We can not see Value through iron, so we call it opaque. Is black ink opaque, or is it trans1.6 parent?

No. 7.

A boy goes to school in the morning, goes home at noon for lunch,

Value returns to school at 1 o'clock and returns home at 4 o'clock. How

2.4 many times does he travel between home and school that day? 
No. 11.

"The curfew tolls the knell of parting day,

The lowing herds wind slowly o'er the lea,

The ploughman homeward plods his weary way,

Value And leaves the world to darkness and to me."-(Gray.)

4.0 Study the above quotation carefully. The author lets us know his feeling about the coming of night. If you think his feeling is one of fear and dread, underscore curfew. If his feeling is one of peace and gladness, underscore ploughman.

It will be noticed that each exercise has been evaluated in terms of a common unit. A pupil's score is the sum of the values of the exercises which the pupil does correctly in five minutes. In Table I there are given the median scores for the first-, second-, and third-class cities of Kansas, for Iowa, and for the other states by groups. In addition to the median scores there is given the number of pupils taking the tests in each group of states. The total number of scores included in this table is more than 100,000 . In most of the cities all the pupils enrolled in the several grades were tested, or in the case of some of the larger cities the tests were given to a sufficient number of pupils to make certain the representative character of the results. In the case of a very few cities the tests were secured by individual teachers and given only to the pupils in one or two buildings.

Strictly speaking a score is not a measure of a pupil's ability. A score represents only a pupil's performance at a given time under given conditions. Any change of conditions will produce corresponding changes in his performance. Conditions include such things as the time allowance, physical conditions, temperature, humidity, lighting, and the emotional status of the pupil. In general it is probable that standard conditions have prevailed in the giving of the tests, but in the case of particular pupils it no doubt has happened that conditions were not standard. Possibly the pupil's own physical condition was not standard, or his pencil point may have broken, or his emotional status may have not been standard, or he may not have possessed at this particular time his normal mental alertness.

The presence of many of the standard conditions depends upon the examiner, and it may have happened that certain examiners produced conditions which materially affect the scores of the pupils whom they tested. They may have done this by urging the pupils to work rapidly in giving the directions for the test or by suggesting to the pupils that they were in competition with pupils in other schools. It may be that some examiners, because 
they felt rather excited themselves, made the pupils unduly excited.

Performance, therefore, is subject to wide variations. Ability can not be measured. It can be inferred accurately from performance only when we know of the conditions attending the performance. We may assume that standard conditions prevailed, but in making inferences regarding the ability of particular pupils or particular classes, the fact of this assumption must not be forgotten.

A few of the very high medians may be due to the fact that the pupils tested were not representative of the schools. In some cases it appears probable that the high median is due to the fact that they are based upon scores from only a small number of pupils who are clearly not representative of their group. For example, this is doubtless true of the tenth-grade median for Kansas second-class cities and of the twelfth-grade median of the southern states. The total medians and the medians for Kansas and Iowa are represented graphically in Fig. 1. The total medians are represented by the heavy solid line, the Kansas medians by the light solid line, and the Iowa medians by the broken line. In studying this figure it should be remembered that Test I was used for grades 3, 4, 5, and Test II for grades $6,7,8$. This change in tests probably accounts for the apparent lack of increase in ability to read silently from grade 5 to grade 6. A similar change of tests occurs between the eighth and ninth grade, but apparently this change did not affect the scores in the same way as the change of tests at the sixth grade.

The median scores for Kansas agree very closely with the total median scores. It is interesting to note that the median scores for Iowa are conspicuously above the total medians and the Kansas medians. A similar condition exists in the case of arithmetic. ${ }^{1}$ Apparently the public schools of Iowa are able to do superior work in these subjects.

The reports from the several states have been grouped into five sections and the median scores for each group given in Table I. The median scores for the several groups of states agree rather closely, on the whole, where the number of pupils tested is one hundred or more. There are, however, some slight variations which are rather interesting. The median scores for the

\footnotetext{
1 See Second and Third Annual Report of the Bureau of Educational Measurements and Standards, Kansas State Normal.
} 
Figure 1

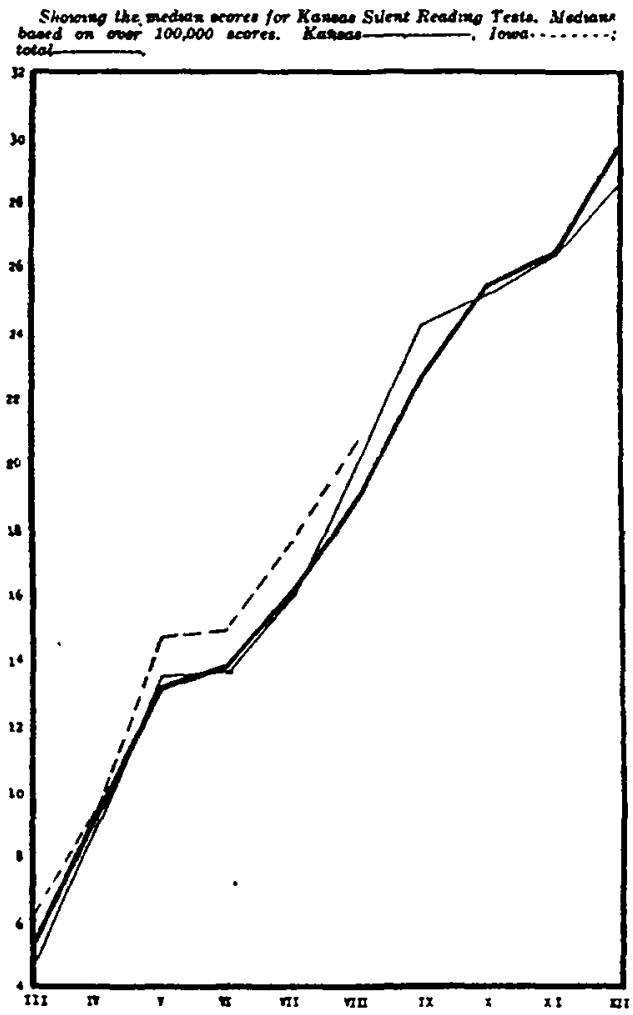

South Atlantic states are, on the whole, the lowest. It was hoped that we would secure some additional reports, since the medians given here are based almost entirely upon reports from one large southern city. This fact may be sufficient to account for the low medians.

The medians for the Western states are among the highest. Just why these medians should be so much higher than the medians from the other sections of the country is not clear. It may be that the medians are not based upon reports from representative cities. Another possible reason is that in other sections of the country children of foreign parentage are more of a factor. In cities where there are a considerable number of children of foreign parentage it has been found that in general lower scores are made.

Ability to read silently involves two factors: First, rate of silent reading; and second, understanding or comprehension of 
TABLE I.

Kansas Silent Reading Test, Median Scores Based on Ovor 100,000 Scores

\begin{tabular}{|c|c|c|c|c|c|c|c|c|c|c|}
\hline & \multicolumn{2}{|c|}{ III. } & \multicolumn{2}{|c|}{ IV. } & \multicolumn{2}{|r|}{ V. } & \multicolumn{2}{|c|}{ VI. } & \multicolumn{2}{|c|}{ VII. } \\
\hline & M. & Pupils & M. & Pupils & M. & Pupils & M. & Pupils & M. & Pupils \\
\hline $\begin{array}{l}\text { class cities } \\
\text { d-class rities.. } \\
\text {-class cities.. }\end{array}$ & $\begin{array}{l}4.5 \\
5.9 \\
4\end{array}$ & \begin{tabular}{|r|}
$1, \mathbf{8 7 3}$ \\
$\mathbf{9 6 6}$ \\
$\mathbf{3 7 3}$ \\
\end{tabular} & $\begin{array}{l}8.8 \\
9.7 \\
82\end{array}$ & $\begin{array}{r}2,018 \\
1,067 \\
524\end{array}$ & 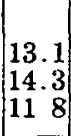 & $\begin{array}{r}1,819 \\
994 \\
471\end{array}$ & $\left|\begin{array}{ll}13 & 8 \\
14 & 3 \\
12 & 5\end{array}\right|$ & $\begin{array}{r}1,590 \\
1,024 \\
518\end{array}$ & $\begin{array}{ll}16 & 1 \\
17 & 3 \\
14 & 0\end{array}$ & $\begin{array}{r}1,546 \\
613 \\
352\end{array}$ \\
\hline $\begin{array}{l}\quad \text { Kansas total. . . } \\
\text { Iowa............ } \\
\text { South Atlantic states. } \\
\text { North Atlantic states. } \\
\text { South Central states } \\
\text { North Central states } \\
\text { Western states... . }\end{array}$ & $\begin{array}{l}4.9 \\
6.2 \\
6.0 \\
5.3 \\
4.7 \\
5.1 \\
6.1\end{array}$ & $\begin{array}{r}3,212 \\
2,371 \\
398 \\
5,780 \\
686 \\
6,358 \\
2,282\end{array}$ & \begin{tabular}{rr|}
9 & 0 \\
9 & 5 \\
9 & .2 \\
9 & .6 \\
8 & 4 \\
9 & .3 \\
10.6
\end{tabular} & $\begin{array}{r}3,609 \\
2,940 \\
350 \\
3,658 \\
723 \\
6,453 \\
2,509\end{array}$ & \begin{tabular}{ll|}
13 & 4 \\
14.6 \\
13 & 9 \\
12 & 9 \\
12 & 3 \\
13 & 1 \\
14 & 4
\end{tabular} & \begin{tabular}{|r|}
3,284 \\
2,695 \\
332 \\
4,020 \\
702 \\
6,540 \\
2,643
\end{tabular} & $\mid \begin{array}{ll}13 & 7 \\
14 & 8 \\
11 & .6 \\
13 & 6 \\
11 & 8 \\
13 & 6 \\
15 & .0\end{array}$ & $\begin{array}{r}3,132 \\
2,597 \\
326 \\
3,168 \\
602 \\
5,762 \\
2,673\end{array}$ & $\begin{array}{l}16.1 \\
17.7 \\
14.5 \\
16.7 \\
15.4 \\
16.2 \\
18.0\end{array}$ & $\begin{array}{r}2,511 \\
2,143 \\
179 \\
3,183 \\
498 \\
5,374 \\
2,508\end{array}$ \\
\hline Grand total & 5.3 & 21.087 & 95 & 20,24 & 150 & 20,21 & 91 & 18,260 & $\overrightarrow{162}$ & 16,396 \\
\hline
\end{tabular}

TABLE I.-Concluded

\begin{tabular}{|c|c|c|c|c|c|c|c|c|c|c|}
\hline & \multicolumn{2}{|c|}{ VIII. } & \multicolumn{2}{|c|}{ IX. } & \multicolumn{2}{|r|}{$\mathrm{X}$. } & \multicolumn{2}{|r|}{ XI. } & \multicolumn{2}{|c|}{ XII. } \\
\hline & M. & Pupils & M. & Pupils & M. & Pupils & M. & Pupils & $\mathrm{M}$. & Pupils \\
\hline $\begin{array}{l}\text { First-class cities. } \\
\text { Second-class cities } \\
\text { Third-class cities.. }\end{array}$ & $\left|\begin{array}{ll}19 & 7 \\
20 & 6 \\
20 & .6\end{array}\right|$ & $\begin{array}{r}1,334 \\
596 \\
560\end{array}$ & $\left|\begin{array}{ll}25 & 3 \\
33 & .7 \\
20 & 6\end{array}\right|$ & $\begin{array}{r}317 \\
72 \\
346\end{array}$ & $\left|\begin{array}{ll}27 & 1 \\
33 & 6 \\
23 & 7\end{array}\right|$ & $\begin{array}{r}199 \\
32 \\
289\end{array}$ & $\left|\begin{array}{ll}27 & 8 \\
26 & 0\end{array}\right|$ & $\begin{array}{l}201 \\
262\end{array}$ & 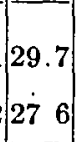 & $\begin{array}{r}115 \\
250\end{array}$ \\
\hline $\begin{array}{l}\text { Kansas total. . . } \\
\text { Iowa. . . . . } \\
\text { South Atlantic states. } \\
\text { North Atlantic states. } \\
\text { South Central states } \\
\text { North Central states } \\
\text { Western states ... }\end{array}$ & $\left|\begin{array}{ll}20 & 1 \\
20 & 6 \\
15 & 8 \\
17 & 8 \\
19 & 2 \\
18 & 2 \\
20 & 6\end{array}\right|$ & $\begin{array}{r}2,490 \\
1,819 \\
179 \\
1,948 \\
350 \\
5,060 \\
2,075\end{array}$ & $\left|\begin{array}{ll}24 & 3 \\
21 & 8 \\
24 & 8 \\
22 & 4 \\
21 & .5 \\
23 & .5\end{array}\right|$ & $\begin{array}{r}735 \\
110 \\
345 \\
121 \\
1,356 \\
232\end{array}$ & $\mid \begin{array}{rr}25.2 \\
20.7 \\
28.9 \\
24 & 5 \\
25 & 7 \\
26 & 0\end{array}$ & $\begin{array}{r}520 \\
\cdots 96 \\
122 \\
133 \\
1,045 \\
234\end{array}$ & $\mid \begin{array}{ll}26 & 5 \\
2 & 5 \\
22 & 0 \\
25 & 8 \\
26 & .5 \\
26 & 4\end{array}$ & \begin{tabular}{r|}
463 \\
78 \\
53 \\
68 \\
736 \\
186
\end{tabular} & 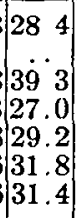 & $\begin{array}{r}365 \\
\times \quad 8 \\
47 \\
74 \\
612 \\
115\end{array}$ \\
\hline Grand total & $\begin{array}{ll}19 & 2\end{array}$ & 13,92 & 229 & 2,899 & 256 & 2,150 & $\begin{array}{ll}26 & 5\end{array}$ & 1,584 & 29.7 & 1,221 \\
\hline
\end{tabular}

the material read. Sometimes this second factor is called quality of reading. In the case of the Kansas Silent Reading Tests these two factors are combined in a single score. The values assigned to the exercises which make up these tests were made proportional to the average length of time required to do the several exercises correctly. Since the two factors are combined in this way, we have no expression of the relative weight of each in the value of the exercises. 


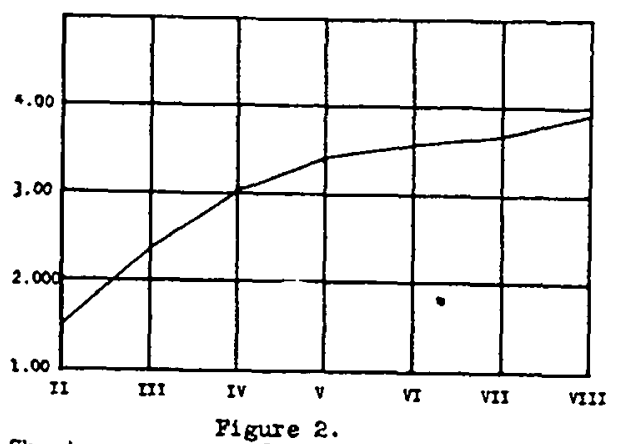

Showing progress of pupils in rote and ollent reading as mesoured by the Gray $\$ 1$ lent Reading Testa.

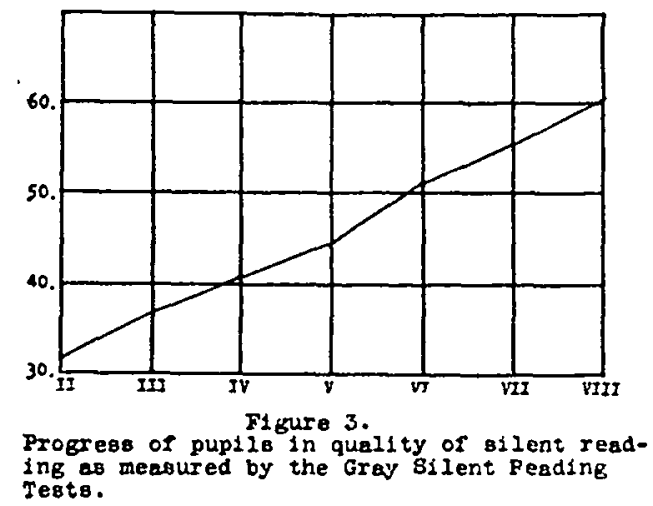

In Figs. 2 and 3 are shown the curves of progress for rate of silent reading and for quality of silent reading as determined by means of the Gray Silent Reading Tests. ${ }^{2}$ The curve of progress for the rate of silent reading, Fig. 2 rises rapidly for the earlier grades and less rapidly in the upper grades, with the partial exception of the eighth grade. This means that the pupil in learning to read increases his rate of silent reading most rapidly in grades 2,3 , and 4 . In the following grades his increase is very slight. When we study the curve of progress for quality of silent reading in Fig. 3 we find that the pupil continues to increase the quality of his silent reading at about the same rate throughout the several grades represented. Apparently the pupils' improvement in silent reading in the upper grades is in quality rather

\footnotetext{
${ }^{1}$ Gray, Willuas S., Studies of Elementary School Reading from Stanulardized Tests, pp. 53-54. Supplementary Educational Monographs, University, of Chicago, No. 1, 1917.
} 
than rate. This increase in quality in the case of the Gray Silent Reading Tests means that the pupils is able to comprehend more difficult passages as well as to comprehend them more fully.

If we compare these two curves of progress with the curve of progress for the Kansas Silent Reading Tests shown in Fig. I, we find the curves of progress for the Kansas Silent Reading Tests corresponds closely. in shape to the curve of progress for quality of silent reading. This fact suggests that the scores made on the Kansas Silent Reading Tests are measures of the quality of silent reading rather than the rate of silent reading. No final conclusion should be drawn from the data presented in these three figures because the tests were not applied to the same group of pupils, but since both of the tests have been used rather widely, particularly the Kansas Silent Reading Tests, it probably is safe to think of the Kansas Silent Reading Tests as placing more emphasis upon comprehension or quality of silent reading than upon rate of silent reading.

It has frequently been asked, What is the effect upon a pupil's score of his acquaintance with the test? No definite study has been made to determine the answer to this question. It has been a rather important question because only one form of the Kansas Silent Reading Tests was available, and if a superintendent wished to know what improvement had been made in silent reading he was forced to repeat the same test.

It is probable that several factors will affect the second set of scores. If the tests have been made the subject of a study by the pupils, without doubt the scores will be much higher. Even if the pupils have been drilled upon the type of reading which these tests call for, doubtless the second set of scores will be much higher than the first set.

In Table II there are given two sets of scores for several cities in which the tests were given the second time and both sets of scores reported to the Bureau of Educational Measurements and Standards. A study of this table will show that in certain cases the scores of the second set are conspicuously higher than those of the first set. In certain other cases they are lower. The facts of this table suggest that the pupil's acquaintance with the tests, through merely having taken it, does not greatly influence a second score. Otherwise it would be difficult to understand how a second set of scores might be lower than the first set. 
TABLE II.

Cities Giving the Tests Tunce

\begin{tabular}{|c|c|c|c|c|c|c|c|c|c|c|c|}
\hline City & Date & III. & IV. & V. & VI. & VII & VIII. & IX. & $\mathrm{X}$. & XI. & XII. \\
\hline $\begin{array}{l}\operatorname{LXXX} \ldots \ldots \\
\operatorname{LXXV} \ldots \ldots\end{array}$ & $\begin{array}{r}11-15 \\
4-16\end{array}$ & $\begin{array}{l}3.1 \\
7.3\end{array}$ & $\begin{array}{r}7.3 \\
11\end{array}$ & $\begin{array}{ll}12 & 4 \\
16.0\end{array}$ & $\begin{array}{l}12.1 \\
18.8\end{array}$ & $\begin{array}{ll}13 & 5 \\
20 & 9\end{array}$ & $\begin{array}{ll}18 & 2 \\
27 & 0\end{array}$ & $\begin{array}{ll}22 & 7 \\
30 & 0\end{array}$ & $\left|\begin{array}{ll}25 & 1 \\
28 & 3\end{array}\right|$ & $\begin{array}{ll}20 & 0 \\
34 & 8\end{array}$ & $\begin{array}{l}300 \\
29.5\end{array}$ \\
\hline $\begin{array}{l}\text { XXVII.. } \\
\text { XXVII.. }\end{array}$ & $\begin{array}{l}4-16 \\
3-17\end{array}$ & $\begin{array}{l}35 \\
45\end{array}$ & $\begin{array}{r}7.4 \\
138\end{array}$ & $\begin{array}{ll}12 & 9 \\
14 & 3\end{array}$ & $\begin{array}{l}11.7 \\
132\end{array}$ & $\begin{array}{ll}16 & 3 \\
19.5\end{array}$ & $\begin{array}{ll}18 & 4 \\
21.6\end{array}$ & & & & \\
\hline $\begin{array}{l}\text { CLXXVIII... } \\
\text { CLXVIII... }\end{array}$ & $\begin{array}{r}10-16 \\
4-17\end{array}$ & & $\begin{array}{ll}5 & 0 \\
9 & 7\end{array}$ & $\begin{array}{rr}9 & 4 \\
17 & 6\end{array}$ & $\begin{array}{r}86 \\
11.1\end{array}$ & $\begin{array}{ll}14 & 4 \\
20 & 1\end{array}$ & $\begin{array}{ll}13 & 0 \\
18 & 0\end{array}$ & & $\because$ & & \\
\hline $\begin{array}{l}\text { VIII.. } \\
\text { VIII. . }\end{array}$ & $\begin{array}{l}5-16 \\
2-17\end{array}$ & $\begin{array}{l}4.4 \\
5.9\end{array}$ & $\begin{array}{ll}8 & 0 \\
7 & 5\end{array}$ & $\begin{array}{ll}13 & 0 \\
13 & 7\end{array}$ & $\begin{array}{ll}14 & 0 \\
13 & 7\end{array}$ & $\begin{array}{ll}16 & 8 \\
15 & 0\end{array}$ & $\begin{array}{ll}26 & 3 \\
19 & 1\end{array}$ & & $\cdots$ & & \\
\hline $\begin{array}{l}\text { XLV... } \\
\text { XLV.. }\end{array}$ & $\left|\begin{array}{c}1-16-17 \\
1-23-17\end{array}\right|$ & 60 & $\begin{array}{c}95 \\
\cdots\end{array}$ & \begin{tabular}{ll|}
14 & 6 \\
$\cdots$ &
\end{tabular} & $\begin{array}{ll}16 & 0 \\
15 & 0\end{array}$ & $\begin{array}{ll}18 & 8 \\
17 & 8\end{array}$ & $\begin{array}{l}22.1 \\
195\end{array}$ & $\cdots$ & $\ldots$ & $\cdots$ & \\
\hline $\begin{array}{l}\text { IXXIII. } \\
\text { LXXIII. }\end{array}$ & $\begin{array}{l}5-16 \\
1-17\end{array}$ & $\begin{array}{ll}2 & 9 \\
2 & 5\end{array}$ & $\begin{array}{l}7.8 \\
6.7\end{array}$ & $\begin{array}{ll}12 & 5 \\
10 & 9\end{array}$ & $\begin{array}{ll}11 & 7 \\
10 & 7\end{array}$ & $\begin{array}{ll}14 & 6 \\
12 & 8\end{array}$ & $\begin{array}{ll}13 & 0 \\
14 & 7\end{array}$ & & . & & \\
\hline $\begin{array}{l}\text { CVIII.. } \\
\text { CVIII.. }\end{array}$ & $\begin{array}{l}9-16 \\
1-17\end{array}$ & $\begin{array}{ll}0 & 0 \\
\ldots & \end{array}$ & $\begin{array}{cc}3 & 5 \\
\cdots & \end{array}$ & $\begin{array}{c}70 \\
.\end{array}$ & 80 & 165 & $\begin{array}{ll}21 & 0\end{array}$ & $\begin{array}{l}192 \\
180\end{array}$ & $20.3 \mid$ & $\begin{array}{ll}25 & 0 \\
33 & .3\end{array}$ & $\begin{array}{ll}20 & 0 \\
40 & 0\end{array}$ \\
\hline $\begin{array}{l}\text { CXXXI } \\
\text { CXXXI }\end{array}$ & $\begin{array}{r}9-16 \\
1-17\end{array}$ & $\begin{array}{r}8 \\
66 \\
\end{array}$ & $\begin{array}{rr}5 & 0 \\
11 & 0 \\
\end{array}$ & $\begin{array}{rr}6 & 4 \\
12 & 3 \\
\end{array}$ & $\begin{array}{ll}13 & 0 \\
18 & 0 \\
\end{array}$ & $\begin{array}{ll}15 & 0 \\
18 & 0 \\
\end{array}$ & $\begin{array}{ll}16 & 7 \\
21 & 6 \\
\end{array}$ & & & &. \\
\hline
\end{tabular}

In Table III there are given the median scores for several adult groups to whom the tests were given. Generally these groups were teachers assembled in institute or students in education classes. These medians have no special significance aside from indicating the scores which may be expected of adults.

TABLE III.

Showing Median Scores for Adults

\begin{tabular}{|c|c|c|}
\hline Test & Medians & $\begin{array}{l}\text { Number } \\
\text { tested }\end{array}$ \\
\hline 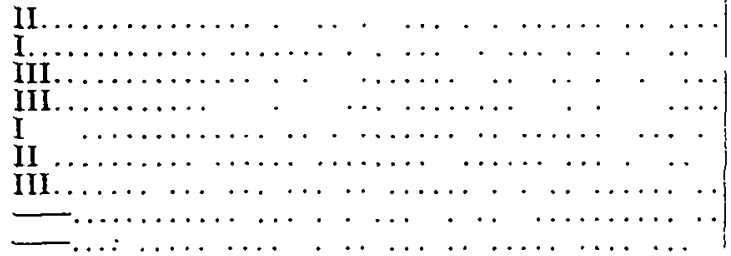 & $\begin{array}{ll}34 & 6 \\
18 & 5 \\
35 & 0 \\
35 & 8 \\
23 & 0 \\
32 & 0 \\
40 & 4 \\
36 & 8 \\
34 & 8\end{array}$ & $\begin{array}{r}54 \\
62 \\
64 \\
330 \\
65 \\
65 \\
65 \\
36 \\
37\end{array}$ \\
\hline
\end{tabular}

Numerous criticisms have been made of the Kansas Silent Reading Tests. A number of these are probably valid and significant. Only a few of the criticisms reported to the Bureau of Educational Measurements and Standards have had to do 
with insignificant details. The most frequent criticism has been concerning the character of the exercises. It has been pointed out that the exercises partake of the nature of puzzles, a very large number of them being arithmetical in nature. For this reason they are not typical reading material. This criticism is obvious to any one who examines the tests, and was very obvious to the author of the tests before they were published for distribution. The author attempted to eliminate this defect of the tests, but it was found impossible at that time. Granted that this criticism is valid, it remains to determine just how much it limits the significance of the scores obtained.

The above characteristic of the test was due largely to the fact that an effort was made to have the tests objective; that is, to have them of such a nature that a minimum of opinion would be exercised in marking the papers. This is a feature which is very important and which is not true of most of the reading tests which have been devised. The question might well be raised whether or not it was worth while to sacrifice other things to obtain this feature.

It has also been said that the ability measured by these tests was the ability to reason rather than to read; that in ordinary reading the mental processes involved were not those of reasoning, hence the scores obtained by means of these tests had no particular significance with reference to reading. The significance of this criticism of course depends upon what reading is. Certainly the exercises of these tests do have to do with the ability which occurs in some reading. It is probably true that a more satisfactory test could be devised by securing exercises which are more nearly like the ordinary reading material which the child meets in the elementary school.

A number who have used the tests have taken occasion to say that they found the tests very easy to administer and requiring only a small amount of time. In fact, no one has reported any difficulty in using the tests, or has even asked questions about giving them. This fact is significant, because teachers can not be expected to use tests which they do not understand or which require an unusual expenditure of time. 